\title{
Perceptions of Teachers towards the STEM Education and the Constructivist Education Approach: Is the Constructivist Education Approach Preparatory to the STEM Education? ${ }^{i}$
}

\author{
Sevda Koç Akran 1,", Sevim Aşiroğlu \\ ${ }^{1}$ Faculty of Education, Siirt University, Turkey \\ ${ }^{2}$ Faculty of Education, Maltepe University, Turkey
}

Copyright $\bigcirc 2018$ by authors, all rights reserved. Authors agree that this article remains permanently open access under the terms of the Creative Commons Attribution License 4.0 International License

\begin{abstract}
The main purpose of this study is to identify the perceptions of the teachers towards the stem education and the constructivist education approach. The study group of the research consists of 40 primary school teachers, 30 mathematics teachers, 20 science teachers and 15 information technologies teachers, who serve in the city center of Siirt and Batman. Data collection tool of the research, which is a phenomenography study, is a semi-structured interview form developed by the researchers. In the study, the data obtained from the interview form was subjected to the descriptive and content analysis methods. As a result of the research, it was concluded that the primary school teachers have positive and negative perceptions towards the STEM education whereas the information technologies teachers have negative perceptions. It was also concluded that mathematics and science teachers have a positive perception of STEM education. Based on the result of the study, some suggestions were presented.
\end{abstract}

Keywords Education, Teacher Perceptions, STEM, STEM Education, Constructivist Education

\section{Introduction}

STEM means root in English. STEM is an acronym and stands for Science, Technology, Engineering and Mathematics [1]. STEM is an educational approach that; transforms theoretical knowledge learned by students in the field of Science, Technology, Engineering, Mathematics into the practice; aims to encourage the students to make innovative and original discoveries; constructs the knowledge on the whole-part relationships; and is recently recommended in many teaching programs in the world [2]. Because, the individuals who receive STEM training are expected to be successful in their future business life, to adapt to the business life easily, and to contribute to the development of the country [1].Because of this expectations, today STEM is considered to be an interdisciplinary approach covering the whole education process from the preschool education to the higher education in the world. Students are analyzing, synthesizing, evaluating, and developing a critical approach by using the information they have acquired from the different disciplines through STEM. This approach of the students towards the information cannot be provided by the STEM education alone, but also the curriculums in which constructivist education is applied are needed. But there are different and similar aspects of both approaches in terms of conveying/using the information to the students. For example, both the STEM education and the constructivist education approach emphasize on the problem-based learning and the project-based learning. However, STEM dwells on these two learning approaches more and lays emphasis on the need of application of these approaches in schools more. It has been seen that STEM education gives the information about how the senior skills will contribute to the future business life of the individuals, whereas the constructivist education approach focuses on how these skills affect the individual's future professional knowledge and skills and the resulting economic benefits.

STEM is not a model, teaching technique, or a strategy. STEM is an approach that is the continuation of the constructivist education approach. It is easier to write and implement different activities for different disciplines in the constructivist education approach whereas every activity is not used not in STEM. There are some differences as well as similarities in the teacher profiles 
using the STEM and the constructivist education approach. Both in the STEM and in the constructivist education approach it is aimed to educate individuals who use the technology, are literate, and have high self-confidence. When achieving such a goal, the teacher is a "guide" in both approaches. But, the boundaries of this guidance task are drawn more clearly at STEM. For example, in STEM education, the teacher should; provide an environment that enhances the self-confidence of the students so that the student is not afraid of making mistakes; provide the students with the theoretical and practical information that will enable them to have high-level thinking skills as well as the theoretical information in Science, Technology, Engineering and Mathematics courses; help the students make innovations with this information. Whereas, in the constructivist education approach the teacher should generally represent the role model who constructs the appropriate skills and gives the students high-level skills.

As seen above, both the STEM and the constructivist education approach have similar and different aspects. Today, there are few studies and researches that reveal this difference and similarity. However, in the developing and changing world and in an age of constantly renewing information it is necessary to take into consideration the different approaches and conduct research in this subject. It is seen that there are very few studies on STEM, and many researches on the constructivist education approach have been carried out. If we want to educate people who keep up with the times, instead of adhering to a single approach, we can integrate the approaches close to this or alternative approaches into the programs, taking into account the structure of society and the education system. Today developed countries strive for using STEM education and other educational approaches in their programs and evaluating their results. A number of steps are being taken in the field of STEM education in our country. These steps should be taken without ignoring the relationship of STEM education with the constructivist education approach that is currently applied. Because, STEM is the continuation of the constructivist education approach and has different aspects as well as similar aspects. It should not be forgotten that the best group to analyze these differences are the teachers. From this point of view, the perception of teachers towards the STEM education and the constructivist education approach and the opinions of the teacher about whether the constructivist education approach is preparatory to the STEM education have been identified as the research problem sentence. In accordance with this problem, the answers were sought for the following questions asked to teachers trained by STEM researchers:

1. What are their perceptions related to the STEM education?

2. What are their perceptions related to the constructivist education approach?
3. What are their perceptions related to the similar aspects of the STEM education and the constructivist education approach?

4. What are their perceptions related to the different aspects of the STEM education and the constructivist education approach?

\section{Materials and Methods}

\subsection{Research Model}

In the research, an election was made among the primary school teachers and branch teachers based on volunteerism in order to identify the opinions of the teachers about the STEM education, the constructivist education approach and the question of "Is the constructivist education approach preparatory to the STEM education?" The researchers gave an informative training to the teachers about the STEM education two hours per week for a total of four weeks. The main purpose of this training is to ensure that teachers have the information about the STEM education and that they understand the similarities and differences between the STEM and the constructivist education approach. In this research, phenomenography was used as a qualitative research method to determine how the teachers perceive the similarities and differences between the two approaches upon the given training. Phenomenographic research focuses on "phenomena that we do not have an in-depth and detailed understanding." [3]. The phenomena can be confronted as any perception, experience or event.

\subsection{Study Group of the Research}

The study group of the research consists of the primary school teachers and branch teachers, who serves in the city center of Siirt and Batman. In the study, 40 primary school teachers, 30 mathematics teachers, 20 science teachers, and 15 information technologies teachers were reached. While the primary school teachers and branch teachers are being determined, the voluntary participation of the teachers in the training about the STEM education has been taken into consideration.

\section{Data Collection Tool of the Research}

As the data collection tool of the research a "semi-structured interview form" developed by the researchers is used.

In the research, a semi-structured interview form consisting of three "open-ended" questions to ask teachers questions about personal information and their perceptions about STEM education and constructivist education was prepared and presented to two experts to determine the validity of the interview form. Experts expressed opinions 
using the triple likert as "Eligible", "Not Applicable", "Corrected" in order to determine whether the questions in the interview form are appropriate for interview purposes. The necessary remedies have been made in line with the expert opinions and the interview form has been made ready for implementation. Using this prepared form, 15-20 minutes interviews were held with school and branch teachers in the school library, reading room. These interviews were made using the recorder. Meetings with teachers were held on different days.

\subsection{Analysis of Data}

In the study, the data obtained from the interview form was subjected to the descriptive and content analysis methods. Descriptive analysis and content analysis methods were used in the analysis of qualitative data. In the descriptive analysis method, "the obtained data are summarized and interpreted according to the predetermined theme. In content analysis, "... a deeper process and concepts and themes that are not recognized by a descriptive approach can be explored in this analysis" [3]. The data obtained from the interviews with the advisor teachers in the study were deciphered by listening to the voice recordings.

\section{Findings and Interpretation}

\subsection{Findings on How the Teachers Perceive the STEM Education}

The findings on how the teachers perceive the STEM education are presented in Table 1 .

As seen in Table 1, the question of "What are their perceptions towards the STEM education?" were asked to the primary school teachers and the branch teachers. In the descriptive analysis of the opinions of the 40 primary school teachers, it was found that they have the following positive and negative perceptions towards the STEM education. Positive perceptions:[Problem-focused study $(\mathrm{f}=7)$, a society that produces $(\mathrm{f}=6)$, an individual who takes risk $(\mathrm{f}=6)$, increasing life skills $(\mathrm{f}=5)$, developing talent $(\mathrm{f}=3)$, self-confidence $(\mathrm{f}=2)$, self-esteem $(\mathrm{f}=2)$, entrepreneurship ( $\mathrm{f}=2)$ ]; negative perceptions:[inadequacy of technology infrastructure of the schools ( $\mathrm{f}=4)$, difficult to apply in pre-school education ( $\mathrm{f}=2$ ), lack of team spirit among teachers $(\mathrm{f}=2)$, difficulty of preparing a program suitable for the STEM $(\mathrm{f}=2)$, difficulty of implementing the problem-based education $(\mathrm{f}=2)]$.

As seen in Table 1, in the descriptive analysis of interviews conducted with 65 branch teachers as well as the primary school teachers, it was found that 30 mathematics and 20 science teachers have "positive perceptions" towards the STEM education. Positive perceptions of the mathematics teachers:[doing problem-based teaching activities $(\mathrm{f}=6)$, integrating the information $(\mathrm{f}=5)$, do activities by using computer technology $(\mathrm{f}=5)$, use of reasoning ways $(\mathrm{f}=5)$, integrating the information about the science and mathematics ( $\mathrm{f}=4)$, performance-based instruction $(\mathrm{f}=4)$, project-based teaching $(\mathrm{f}=4)$, using the 5Emodel in activities $(\mathrm{f}=1)]$; Positive perceptions of the Science teachers:[integrating real life problems with different disciplines ( $\mathrm{f}=3$ ), educating the individuals who can apply the theoretical knowledge $(\mathrm{f}=2)$, ability to integrate the applications made in laboratories with the information from different disciplines $(\mathrm{f}=2)$, ability to integrate the information acquired through the digital teaching technologies with the aim of the course $(\mathrm{f}=2)$, ability to make different inventions $(\mathrm{f}=2)]$.

Negative perceptions of the 15 information technologies teacher:[the inadequacies in gaining the aims of different disciplines of technology $(\mathrm{f}=4)$ the inadequacies of the learning environments in applying the modern approaches $(\mathrm{f}=3)$, the difficulty in preparing activities for science, mathematics and engineering by using technology $(\mathrm{f}=3)$, the inadequacies in gaining the top-level skills with technology $(\mathrm{f}=3)$, the inability to transfer the skills gained by different disciplines to daily life with technology $(\mathrm{f}=2)]$.

Table 1. The descriptive analysis results of-how the teachers perceive the STEM education

\begin{tabular}{|c|c|c|c|c|c|c|}
\hline \multirow{2}{*}{$\begin{array}{l}\text { Interview } \\
\text { Questions }\end{array}$} & \multirow{2}{*}{ Branch } & \multirow{2}{*}{ Category } & \multicolumn{2}{|c|}{ Source } & \multicolumn{2}{|c|}{ Coding Density } \\
\hline & & & f & $\%$ & f & $\%$ \\
\hline \multirow{7}{*}{$\begin{array}{l}\text { What are their } \\
\text { perceptions } \\
\text { towards the } \\
\text { STEM } \\
\text { education? }\end{array}$} & \multirow{3}{*}{ Primary school teachers } & Positive perceptions & 25 & 62,5 & 33 & 73,33 \\
\hline & & Negative perceptions & 15 & 37,5 & 12 & 26,67 \\
\hline & & TOTAL & 40 & 100 & 45 & 100 \\
\hline & Mathematics teachers & \multirow{2}{*}{ Positive perceptions } & 30 & 54,54 & 34 & 57,63 \\
\hline & Science teachers & & 10 & 18,28 & 10 & 16,95 \\
\hline & \multirow{2}{*}{ Technologies teachers } & Positive perceptions & 15 & 27,28 & 15 & 25,42 \\
\hline & & TOTAL & 55 & 100 & 59 & 100 \\
\hline
\end{tabular}


As is seen, it can be argued that; the problem-focused studies/activities can be done with the STEM for primary school teachers (e.g.1-2-3-4-5-6-7) and mathematics teachers (e.g.8-9-10-11-12-13); the real life problems are related to the problems in other courses for the science teachers (14-15-16); the technological tools used in the STEM education will not be able to be sufficient to gain the knowledge and skills that the different disciplines try to achieve for the information technologies teachers (e.g. 17-18-19-20).

[1] "STEM education is like a mirror of real life. An education that leaves people face to face with the facts." (S7)

[2] "...STEM covers the problems of every aspect of our life."(S9)

[3] "Life is full of hurdles. We can sometimes get rid of these hurdles with the education we take. Just like the STEM." (S12)

[4] "With the STEM education, the individuals seek solutions to the problems they face."(S17)

[5] "STEM education gives the information about how an individual should behave in a problem he/she faces." (S27)

[6] [ "In the learning-teaching process, STEM increases the level of awareness of the individual about the problem." (S36)

[7] "With STEM, the individual can learn to look at the problems from different angles" (S37)

[8] "...with this education, the individual's ability to analyze is developing."(M16)

[9] "Students learn to look at the events in a multifaceted way through STEM education"(M18)

[10] "STEM education provides a cause-and-effect relationship between different events in the class."(M23)

[11] "... the student comprehends that there are different solutions to a problem with the STEM education." (M24)

[12] "the individual can solve the problem by critically approaching the event in the activities done with the STEM."(M29)

[13] "... individuals use different ways of reasoning with this education in the problem-based activities."(M30)

[14] "the students can transfer the problem faced in science to the real life."(F4)

[15] "the student can also transfer the solution of the problem learned in the course to the daily life."(F8)

[16] "the students can transfer the solution of the different problems to the area where they live"(F12)

[17] "We cannot always acquire the gains of the science lessons by using the STEM education."(B3)

[18] "How can we gain the benefits of abstract lessons with technology? Especially with a modern approach."(B4)
[19] "The good thing about the STEM is that it prioritizes the problem-solving skills."(B12)

[20] "To what extent can achieve the goals if we use the smart board in STEM education? Can we concretely see this on the student? It can be discussed, but I do not look positively." (B13).

\subsection{Findings on How the Teachers Perceive the Constructivist Education}

The findings on how the teachers perceive the constructivist education are presented in Table 2.

As seen in Table 2, the primary school teachers and branch teachers were asked the questions of "What are their perceptions about constructivist education?" In the descriptive analysis of the opinions of the 40 primary school teachers, among the constructivist education's "perceptions towards the learning-teaching process" are the following:[suggesting different method-techniques $(\mathrm{f}=8)$, emphasizing the learning preferences of students $(\mathrm{f}=6)$, giving importance to the technology in the learning process $(\mathrm{f}=6)$, using traditional classroom layout in applications $(\mathrm{f}=6)$, evaluating the student during the process and in the final( $\mathrm{f}=5)$, an education that does not take into account the developmental characteristics of the student $(\mathrm{f}=3)$ ]. Besides this, the perceptions of the primary school teachers regarding the constructivist education towards the "student profile" are the following:[a student who cannot use the senior skills $(f=4)$, a student who does not have a sense of curiosity ( $\mathrm{f}=3$ ), a student who cannot invent $(\mathrm{f}=3)$, a student who memorizes the information ( $\mathrm{f}=2)$, a student who takes into account the whole-part relationship $(\mathrm{f}=2)$, an entrepreneur student $(f=2)$, a student who associates the information with daily life $(\mathrm{f}=1)]$. The primary school teachers' "perceptions towards the teacher profile" are the following:[a teacher who guides $(\mathrm{f}=3)$, a teacher who does not include the problem-focused activities in the learning-teaching process $(\mathrm{f}=2)$, a teacher who transforms theoretical knowledge into practice $(\mathrm{f}=2)$, a non-creative teacher $(\mathrm{f}=2)$, a teacher with self-esteem $(\mathrm{f}=2)$, a teacher who is willing to use the technological tools $(f=2)$, a teacher who is open to the innovations $(\mathrm{f}=1)]$.

In the descriptive analysis of the interviews conducted with 65 branch teachers, the mathematics teachers'" perceptions towards the program "are the following:"[the student cannot use some gains of the program in daily $\operatorname{life}(\mathrm{f}=6)$, the majority of the method-techniques recommended in the program are unknown $(\mathrm{f}=5)$, the traditional teacher profile is preferred to the teacher profile in the program $(\mathrm{f}=5)$, the students are passive in the learning process $(\mathrm{f}=5)$, many of the measurement and evaluation techniques proposed in the program are not used $(\mathrm{f}=5)$, the time is inadequate in the learning process $(\mathrm{f}=4)]$. 
Table 2. The Descriptive Analysis Result of How The Teachers Perceive The Constructivist Education

\begin{tabular}{|c|c|c|c|c|c|c|}
\hline \multirow{2}{*}{$\begin{array}{l}\text { Interview } \\
\text { Questions }\end{array}$} & \multirow{2}{*}{ Branch } & \multirow{2}{*}{ Category } & \multicolumn{2}{|c|}{ Source } & \multicolumn{2}{|c|}{ Coding Density } \\
\hline & & & f & $\%$ & f & $\%$ \\
\hline \multirow{8}{*}{$\begin{array}{l}\text { What are their } \\
\text { perceptions } \\
\text { about } \\
\text { constructivist } \\
\text { education? }\end{array}$} & \multirow{4}{*}{ Primary school teachers } & $\begin{array}{l}\text { Perceptions towards the } \\
\text { learning-teaching process }\end{array}$ & 25 & 54,45 & 34 & 52,31 \\
\hline & & Perceptions towards the students profile & 12 & 26,09 & 17 & 26,16 \\
\hline & & Perceptions towards the teacher profile & 9 & 19,56 & 14 & 21,53 \\
\hline & & TOTAL & 46 & 100 & 65 & 100 \\
\hline & Mathematics teachers & \multirow{2}{*}{ Perceptions towards the program } & 30 & 46,15 & 30 & 44,78 \\
\hline & Science teachers & & 20 & 30,77 & 22 & 32,84 \\
\hline & \multirow{2}{*}{ Technologies teachers } & Perceptions towards the technological & 15 & 23,08 & 15 & 22,38 \\
\hline & & TOTAL & 65 & 100 & 67 & 100 \\
\hline
\end{tabular}

The "perceptions" of the science teachers regarding the constructivist education "towards the program" are the following:[modern approaches in the program are not used in the learning environment $(\mathrm{f}=5)$, it is not known how to use each theoretical knowledge in practice $(\mathrm{f}=4)$, the study areas in which the recommended practical information will be used are inadequate $(\mathrm{f}=4)$, different measurement and evaluation techniques are used $(\mathrm{f}=4)$, attention is paid to the parts-whole relation among the subjects $(\mathrm{f}=3)$, the spiral approach is taken into account in the program $(\mathrm{f}=2)]$.

Information technologies teachers' "technological perceptions" towards the constructivist education approach are the following: [the information is being concretized by the technological tools $(\mathrm{f}=4)$, the program is not able to guide teachers in using different technological tools $(\mathrm{f}=3)$, students' readiness for the technology is not enough $(\mathrm{f}=3)$, the constructivist education adopts an understanding intertwined with technology $(\mathrm{f}=3)$, provide students with technology literacy $(\mathrm{f}=2)]$.

As is seen, according to the primary school teachers, different methods and techniques(such as drama, brain storming, fishbone, case study, problem solving) are used in the learning-teaching process with the constructivist education(e.g. 21-22-23-24-25-26-27-28), the students do not use their high level skills enough with this education(e.g. 29-30-31-32), the teacher becomes a guide to the students with this education (e.g. 33-34-35).

According to the mathematics teachers, students cannot transfer every gains to daily life with constructive education(e.g. 36-3-38-39-40); according to the science teachers, modern approaches are not used in the learning environment (e.g.41-42-43-44-45); according to the information technologies teachers, the information becomes meaningful with the technological tools used in the class (e.g. 46-47-48-49).

[21] "Today, we use a variety of methods and techniques."(S1)

[22] "The most notable aspect of the new program is the inclusion of a student-centered methodology."(S3)
[23] “...constructivism offers the methods and techniques different from the traditional education."(S18)

[24] "I was not able to use many methods in the past, now I am using everything such as drama, case study."(S40)

[25] "I can easily include the students into the learning process with different methods and techniques."(S23)

[26] "I think that the constructivism is a modern approach that contains good techniques"(S34)

[27] "... the more the method-technique is used, the more the course is joyful...." (S32)

[28] "... I think no approach can substitute for this approach in terms of method and technique diversity."(S4)

[29] "The student just memorizes."(S19)

[30] "... critical thinking, problem solving is not gained in this new program." (S22)

[31] "We give the information and the student gives us the same."(S39)

[32] "we raise passive students, there is no creative individuals"(S14)

[33] "... the guidance of the teacher is utmost important in the learning-teaching process."(S36)

[34] "... in this approach, the student is not alone. There is a teacher guiding the student."(S25)

[35] "in the constructivist education, the teacher is the person who guides the student." (S37)

[36] "...the gains of the mathematics course are not concretized with the constructivist education approach."(M1)

[37] "there are many unnecessary gains in the program"(M17)

[38] "the principle of transfer has been violated a little with the constructivist education approach."(M21)

[39] "learning is not permanent if it remains within the four walls"(M5)

[40] "information cannot be associated with the real life"(M30)

[41] "... its name is constructivist, but I have no information about new approaches"(F2) 
[42] "7E, 5E model is mentioned, I have no idea about them." (F6).

[43] "again and again traditional education. There are no different approaches." (F18)

[44] "... textbooks mention about different approaches, but there is nothing in practice"(F19)

[45] "I am still using the traditional education. I do not have information about the modern approaches." (F20)

[46] "... sometimes I look. Teachers use different technological tools in different courses."(B5)

[47] "... information becomes meaningful when used with different tools"(B9)

[48] "... I attract the attention of the student more when I use different technological tools in the class."(B11)

[49] "When the teacher guidance and the technological tools come together, information becomes meaningful"(B12)

\subsection{Findings on. How The Teachers Perceive the Similar Aspects of the Stem Education And the Constructivist Education Approach.}

Findings on how the teachers perceive the similar aspects of the STEM education and the constructivist education approach are presented in Table 3 .

As seen in Table 3, the question of "how do the teachers perceive the similar aspects of the STEM education and the constructivist education approach?" were asked to the primary school teachers and the branch teachers. In the descriptive analysis of the opinions of the 40 primary school teachers, the following findings are reached regarding their perceptions on the similarities of both concepts about the "construction of the information": [the information is constructed by the student ( $\mathrm{f}=4$ ), old-new information is being associated ( $\mathrm{f}=3$ ), information is being transferred to the different fields ( $\mathrm{f}=3$ ), attention is paid to the whole-part relationship ( $\mathrm{f}=3$ ), information is being taken in the guidance of the teacher ( $\mathrm{f}=3$ ), information is tried to be reached with different methods and techniques $(\mathrm{f}=2)$, information is used to solve the problems encountered ( $\mathrm{f}=2)]$. The perceptions about "the model of the teacher" are the following: [guides the student $(\mathrm{f}=3)$, encourages the cooperation. ( $\mathrm{f}=3$ ), open to the innovation $(\mathrm{f}=3)$, leads the students to problem solving $(\mathrm{f}=3)]$. The perceptions about "the point of view towards the society" are the following: [adheres importance to the school-society interaction $(\mathrm{f}=2)$, information has a field of application $(\mathrm{f}=2)$, adopting the concept of producing society $(\mathrm{f}=1)$, a society that is the laboratory of the individual $(\mathrm{f}=1)$ ].

According to the mathematics teachers, the following "modern approaches" have been identified among the similar aspects of the STEM education and the constructivist education approach: [5E model $(\mathrm{f}=4)$, problem-based learning $(\mathrm{f}=3)$, project-based learning $(\mathrm{f}=3)$, cooperation-based learning ( $\mathrm{f}=2)$ ]; "high level skills:" [problem solving $(\mathrm{f}=3)$, critical thinking $(\mathrm{f}=3)$, creativity $(\mathrm{f}=3)$, reflective thinking $(\mathrm{f}=3)]$; "student-centered concept of education:" [a curious student in the learning process $(\mathrm{f}=2)$, an inventor $(\mathrm{f}=2)$, a student who constructs the information $(\mathrm{f}=2)$, a student who works individually and in a group ( $\mathrm{f}=2)$, a student who analyzes, synthesizes and evaluates the information $(\mathrm{f}=1)]$; in addition, the "philosophical understanding" of the mathematics teachers about the similar aspects of both approaches are the following:[progressivism $\quad(\mathrm{f}=2), \quad$ re-constructionism $(\mathrm{f}=2)]$.

Table 3. The Descriptive Analysis Result of How the Teachers Perceive the Constructivist Education

\begin{tabular}{|c|c|c|c|c|c|c|}
\hline \multirow{2}{*}{$\begin{array}{l}\text { Interview } \\
\text { Questions }\end{array}$} & \multirow{2}{*}{ Branch } & \multirow{2}{*}{ Category } & \multicolumn{2}{|c|}{ Source } & \multicolumn{2}{|c|}{ Coding Density } \\
\hline & & & $\mathbf{f}$ & $\%$ & f & $\%$ \\
\hline \multirow{13}{*}{$\begin{array}{l}\text { How do the } \\
\text { teachers } \\
\text { perceive the } \\
\text { similar aspects } \\
\text { of the STEM } \\
\text { education and } \\
\text { the } \\
\text { constructivist } \\
\text { education } \\
\text { approach? }\end{array}$} & \multirow{4}{*}{ Primary school teachers } & Construction of the information & 20 & 57,14 & 20 & 52,63 \\
\hline & & The model of the teacher & 10 & 28,57 & 12 & 31,57 \\
\hline & & The point of view towards the society & 5 & 14,29 & 6 & 15,78 \\
\hline & & TOTAL & 35 & 100 & 38 & 100 \\
\hline & \multirow{3}{*}{ Mathematics teachers } & Modern approaches & 12 & 16 & 12 & 15,58 \\
\hline & & High level skills & 11 & 14,66 & 12 & 15,58 \\
\hline & & Student-centered concept of education & 9 & 12 & 9 & 11,68 \\
\hline & \multirow{3}{*}{ Science teachers } & The integration of different disciplines & 20 & 26,66 & 21 & 27,27 \\
\hline & & İnternational examinations & 4 & 5,33 & 4 & 5,19 \\
\hline & & Education philosophy & 4 & 5,33 & 4 & 5,19 \\
\hline & \multirow{3}{*}{ Technologies teachers } & Skills gained with technology & 11 & 14,66 & 11 & 14,28 \\
\hline & & The proposals for technology & 4 & 5,33 & 4 & 5,19 \\
\hline & & TOTAL & 75 & 100 & 77 & 100 \\
\hline
\end{tabular}


According to the science teachers, when the similar aspects of the STEM education and the constructivist education approach are considered, it is seen that "the integration of different disciplines" is the following: [the science is related with the mathematics subjects $(\mathrm{f}=6)$, the mathematics is related with the subjects of the science courses $(f=5)$, the mathematics course is related with a technology-weighted course $(\mathrm{f}=5), \quad$ information technologies course is related with the subjects of mathematics $(\mathrm{f}=5)]$. In addition, the science teachers have emphasized the following about "international examinations" in the STEM and the constructivist education approach: [One of the best feedbacks of learning outcomes is TIMSS and PISA results $(\mathrm{f}=2)$, TIMSS results in determining students' mathematics and science status $(\mathrm{f}=2)]$.

The information technologies teachers have formed two categories about the similar aspects of both approaches. The first of these categories is "skills gained with technology" and it is as follows:[able to solve problems $(\mathrm{f}=3)$, inventor $(\mathrm{f}=2)$, has information literacy $(\mathrm{f}=2)$, questioning $(\mathrm{f}=2)$, curious $(\mathrm{f}=1)$, approaches the event critically $(\mathrm{f}=1)$ ]; the latter is "the proposals for technology" and it is as follows: [a teacher who integrates the course with technological tools $(\mathrm{f}=2)$, an environment suitable for the concretization of activities with technological tools $(\mathrm{f}=2)]$.

As is seen, according to the primary school teachers, it can be argued that; the information is constructed by the student in both approaches(e.g. 50-51-52-53); according to the mathematics teachers, different modern approaches are used(e.g. 54-55-56-57); according to the science teachers, some gains of the science course have been tried to be taught with mathematics course (58-59-60-61-62-63); according to thein formation technologies teachers, the students can solve the problems with technological tools more easily[e.g. 64-65-66].
[50] "student is like an engineer in both two approaches" (S6)

[51] "just as in constructivist education, in STEM student is expected to construct the knowledge" (S7)

[52] "Comprehended knowledge become meaningful by these two approaches" (S10)

[53] "student constructs knowledge himself in STEM and constructivist education" (S18)

[54] "there are approaches that I haven't heard in my life in every approach..."(M9)

[55] "there are common contemporary approaches in STEM and constructivism" (M15)

[56] ["that they handle contemporary approaches can be among their common grounds." (M22)

[57] "STEM resembles constructivism in that it handles contemporary approaches" (M26)

[58] "not only science subjects are instructed, support is received also from other courses" (F5)

[59] "....I get help from mathematics subjects if needed" (F6)

[60] "There is not only a course subject in STEM and Constructivism, learning outcomes of many courses exist intertwined" (F11)

[61] "The good point of both two approaches is that there is a relationship between the courses" (F14)

[62] "There is an incredible integration between the courses" (F17)

[63] "student knows where to get the information in both two approaches" (F18)

[64] "student can find solutions from different sources" (B3)

[65] "today is technological age, student finds solutions to problems in a short time by using these approaches" (B10)

[66] "information is not sought far away as before. ..student can reach the solution of every problem easily by technological means. (B14).

\subsection{Findings on how the perceptions of teachers are on different aspects of STEM education and constructivist education approach.}

Table 4. Descriptive analysis results of the perceptions of teachers on different aspects of STEM education and constructivist education approach

\begin{tabular}{|c|c|c|c|c|c|c|}
\hline \multirow{2}{*}{$\begin{array}{l}\text { Interview } \\
\text { Questions }\end{array}$} & \multirow[b]{2}{*}{ Branch } & \multirow[b]{2}{*}{ Category } & \multicolumn{2}{|c|}{ Source } & \multicolumn{2}{|c|}{ Coding Density } \\
\hline & & & f & $\%$ & f & $\%$ \\
\hline \multirow{11}{*}{$\begin{array}{l}\text { What are your } \\
\text { perceptions on } \\
\text { different } \\
\text { aspects of } \\
\text { STEM } \\
\text { education and } \\
\text { constructivist } \\
\text { education } \\
\text { approach? }\end{array}$} & \multirow{3}{*}{$\begin{array}{c}\text { Primary school } \\
\text { teachers }\end{array}$} & Using strategies & 26 & 65 & 26 & 63,41 \\
\hline & & Expectations & 14 & 35 & 15 & 36,59 \\
\hline & & TOTAL & 40 & 100 & 41 & 100 \\
\hline & \multirow{3}{*}{ Mathematics teachers } & The mission & 12 & 8,39 & 12 & 8,21 \\
\hline & & Applying the activities & 10 & 6,99 & 10 & 6,84 \\
\hline & & School profile & 10 & 6,99 & 10 & 6,84 \\
\hline & \multirow{2}{*}{ Science teachers } & The components & 10 & 6,99 & 10 & 6,84 \\
\hline & & Viewpoints on high level skills & 9 & 6,29 & 9 & 6,16 \\
\hline & \multirow{3}{*}{ Technologies teachers } & Literacy skills & 7 & 4,89 & 8 & 5,47 \\
\hline & & Learning-teaching environment & 5 & 3,49 & 5 & 3,42 \\
\hline & & TOTAL & 143 & 100 & 146 & 100 \\
\hline
\end{tabular}


Findings on how the perceptions of teachers are on different aspects of STEM education and constructivist education approach are shown in Table 4.

As seen in Table 4, the question of "What are your perceptions on different aspects of STEM education and constructivist education approach?" was asked to class teachers and branch teachers. In descriptive analysis of the opinions of 40 class teachers, in "using strategies" category [Using teaching strategies by more inventions and research-examination in STEM education $(\mathrm{f}=6)$, more inventions in STEM education ( $\mathrm{f}=5$ ), more presentations in constructivist education approach $(\mathrm{f}=5)$, partial inventions in constructivist education $(\mathrm{f}=5)$, very few research-examination in constructivist education $(\mathrm{f}=5)]$; in "expectations" category [increasing student levels and numbers in mathematics education in STEM education $(\mathrm{f}=4)$, increasing numbers of students whose STEM skills are high $(\mathrm{f}=4)$, integrating STEM education into teacher training programs $(\mathrm{f}=4)$, bringing life-long learning skills in all disciplines in constructivist education $(\mathrm{f}=3)$ ] take place.

As seen in Table 4, 30 mathematics teachers expressed their opinions on "the mission" of STEM education and constructivist education approach. These opinions are that [STEM keeps project-based learning $(\mathrm{f}=4)$ and problem-based learning $(\mathrm{f}=3)$ at the forefront, constructivist education approach keeps different approaches and models for each discipline $(\mathrm{f}=3)$ at the forefront].

In "applying the activities," there are [Every activity is not used in STEM education ( $\mathrm{f}=4)$, there is not any limitation in activities in constructivist education $(\mathrm{f}=2)$, activities in Mathematics, Science, Engineering and Technology are given weight in STEM education $(\mathrm{f}=2)$, there are different activities regarding each discipline in constructivist education approach $(\mathrm{f}=2)]$.

In "School profile," Mathematics teachers had the opinions of [STEM schools are digitally supported $(\mathrm{f}=3)$, consider project-based learning $(\mathrm{f}=2)$, consider engineering design ( $\mathrm{f}=2)$, develop critical thinking skill $(\mathrm{f}=1)$; in constructivist education approach schools bring up individuals appropriate to the learning outcomes of all disciplines $(\mathrm{f}=2)$ ].

According to science teachers, among "the components" of both two approaches are [mathematics, science, technology and engineering $(\mathrm{f}=5)$ in STEM education, different disciplines $(\mathrm{f}=4)$ in constructivist education].

Regarding "Viewpoints on high level skills," [STEM education sees the skills as a contribution to individual's career in the future ( $\mathrm{f}=3$ ), an important step of success in the profession that the individual will choose $(\mathrm{f}=2)$, and constructivist education sees the skills as the contribution of an individual to cognitive dimension in the occupation $(\mathrm{f}=2)$, success of prospective occupation in terms of economical dimension $(\mathrm{f}=2)]$.

On "literacy" according to information technologies teachers, they expressed the opinions that [universal literacy in STEM education ( $\mathrm{f}=3$ ), it considers four components in STEM $(\mathrm{f}=2)$, literacy determined for different disciplines in constructivist education approach $(\mathrm{f}=2)$, there is not a universal literacy skill in all disciplines $(\mathrm{f}=1)]$. Besides, it was observed that "as learning-teaching environment" teachers consider [learning-teaching environment towards four disciplines in STEM education $(\mathrm{f}=3)$, common and different learning-teaching environment towards all disciplines in constructivist education $(\mathrm{f}=2)]$.

As one can see, it can be argued that according to class teachers inventions and research-examination teaching strategy are used more in STEM education (e.g. 67-68-69-70-71-72) and numbers of students should be increased in different disciplines (e.g. 73-74-75-76). Mathematics teachers adopt that project-based learning is emphasized with STEM education (e.g. 81-82-83-84) and a digitally supported school profile (e.g.85-86-87).

According to science teachers, out of two approaches, STEM education contributes to four components (e.g. 88-89-90-91-92) and prospective professional life of high level skills (e.g. 93-94-95).

It can be argued that according to information technologies teachers, a universal literacy skill is obtained with STEM education (e.g. 96-97-98), a learning environment intended for four disciplines is taken into consideration (e.g. 99-100-101).

[67] "STEM education arouses curiosity of students" (S6)

[68] "students discover things with STEM" (S8)

[69] "intuitional thinking and sense of curiosity of students develop with STEM" (S31)

[70] "students do not memorize the knowledge, instead they research with STEM" (S34)

[71] "in STEM education, students construct the knowledge by wondering themselves" (S36)

[72] "in class and out of class activities are conducted with this education" (S40)

[73] "numbers should be increased especially in mathematics field in STEM education" (S1)

[74] "there should exist individuals who use their logical-mathematical intelligence" (S2)

[75] "individuals should be able to solve problems and take a different approach to things...and this is possible with mathematics" (S3)

[76] "individuals should conduct processes and make reasoning on cause effect relationship between these processes" (S10)

[77] "learning of student should not be limited to classroom...he should make projects. (M2)

[78] "Too many tools and materials are used in STEM education and these are reflected to projects" (M9)

[79] "Students search for solutions to problems in context of various scenarios" (M15)

[80] "Students' problem solving skills develop by projects." (M17) 
[81] "there are different activities for mathematics" (M2)

[82] "An activity that is used in science may not appropriate for another course" (M3)

[83] "There are certain activities intended for certain behaviors" (M4)

[84] "there may not be common activities among disciplines" (M34)

[85] “....students' loading obtained data to determined systems...”(M35)

[86] "sharing of materials that are obtained for the courses in digital media..." (M36)

[87] "....using databases and making of activity plans for that.... (M37)

[88] "STEM education takes into account certain components."

[89] "...mathematics, science, technology and engineering are important" (F4)

[90] "There are not many components in STEM. But there are in constructivism." (F8)

[91] "Diversity in terms of courses is low in STEM" (F14)

[92] "Compared to constructivism, STEM rotates around certain disciplines" (F20)

[93] "profession and high level skills are related" (F1)

[94] "STEM is also an important determinant in choice of high level professions in the future(F3)

[95] "economical dimension of a profession is not important, it is important that to what extent an individual will reflect these skills to his profession"(F6)

[96] “...There are literacies on media, knowledge etc. in constructivism, in STEM there is not this emphasis" (B3)

[97] "There is not a separate literacy skill for each discipline"(B8)

[98] "Literacy skill is common in all disciplines"(B9)

[99] "Contrary to constructivism, STEM limits learning environment according to some components"(B10)

[100] "....there is a learning environment suitable for four components" (B13)

[101] "The more components, the more learning environments"(B14)

As one can see, STEM education provides high level skills to individuals and emphasizes that learning can also occur out of the classroom and will contribute to professional skills of individual.

\section{Discussion and Conclusion}

It was observed that class, mathematics and science and technology teachers had positive perceptions on STEM education. According to the teachers, STEM education brings an individual in problem solving skill, arouses an individual's interest in the course and enhances his motivation, enables him to be technological literate and to have creative and critical thinking skills by putting forth different projects. As Morrison [4] argued, children take part in different projects by STEM education, use many technologies in this project training process and this enhances their motivations. Children whose motivations enhance become open to new information and skills. What is important is to continue these skills for the whole life. Because the world we live in changes swiftly. It seems difficult especially for young children and teachers to follow these changes and adapt. Here STEM is an education that helps children and teacher in both children's planning their developmental characteristics and teacher's planning the learning-teaching process in the classroom and how they should use technology [5]. Children make inventions like a researcher in STEM education and converts their knowledge on different disciplines such as Science, Technology, Engineering and Mathematics to practice [1]. Therefore, there is not a single expected outcome of the system in STEM education. Children entering the system gain knowledge and skills with a comprehensive education approach [1] throughout the process. Thus, also in this research, class, mathematics, science and technology teachers opined similarly to these explanations made on STEM education. It was observed that teachers expressed positive opinions on that STEM education provides life skills to children, children handle real life problems and find solutions by STEM and it provides children self-respect, empathy and many other skills. It was concluded that contrary to class, mathematics and science and technology teachers; information technologies teachers had negative perceptions on STEM education. According to information technologies teachers, STEM is not a suitable education program for both current teaching program being implemented and student-teacher profile in our country. Because it is considered difficult to prepare technological activities regarding every discipline (Mathematics, science, engineering, etc.) by using STEM education. Other negative perceptions of information technologies teachers on STEM education are that general structure of schools, classrooms are not equipped with technological tools and materials adequately, teachers and students have inadequate knowledge on how to use technological tools and they are not technological literate. However, STEM education aims an individual to be a good technological literate and to get education intended for that. It is seen that technological developments practiced in education system is not compatible with that purpose of STEM education. This opinion is also declared in conducted researches. It was observed in the researches that individuals could not be technological literate despite interactive board usage in schools and equipping of schools with technological tools and materials as part of Fatih Project. Besides the fact that individuals are not technological literate, it is also seen that they do not have 
self-confidences, their readiness levels are inadequate and teachers do not have enough knowledge to use technological tools and materials. Here STEM education is an approach that takes into account developments of societies and defends implementing concept of education by considering teacher-student profiles, teaching programs and characteristics of disciplines. In other words, it is a concept of education that is advised to be used in contemporary societies in which their goals, processes, outcomes are evident/foreseen and argues for a student-centered learning-teaching process like constructivist education approach.

When the perceptions of Class, Mathematics, Information Technologies and Science and Technology teachers on constructivist education are examined, class teachers stated that this education approach is student-centered. According to class teachers, constructivist education approach takes into account developmental characteristics of students, teacher become a guide to student during learning process, and it uses different methods and techniques [6-7-8]. Constructivist education approach, which is a contemporary approach, enables children to have high level thinking skills and analyze, synthesize and evaluate things at the same time [9]. Children who have these skills are good researchers and problem solvers, and they follow technological developments closely, in short these children are life-long learning individuals. [10]. A life-long learning individual questions things starting from early ages. He discovers the world with sense of curiosity. He relates knowledge with the real world instead of memorizing them. In spite of the positive perceptions of class teachers on constructivist education, it was observed that Mathematics, Information Technologies and Science and Technology teachers had negative perceptions. Mathematics, Information Technologies, and Science and Technology teachers stated that subjects are not materialized, learning is not permanent, they do not have information on many contemporary models, knowledge stay at theoretical level and are not converted into practice, and they cannot use many technological tools with this education approach. According to Brooks and Brooks [11], in classes in which constructivist education approach is applied, voice of students more than that of teachers are heard and teacher cannot use enough time to make activities. Activities that are found in ranging from teacher's guide books to other sources do not attract the attention of students and students' motivations decrease. In especially courses that students have problems in understanding and perceiving such as mathematics and science and technology, students' academic self-confidences decrease because of applications in these books and program. As well as students, teachers' teaching motivation also decrease during this process. Many researchers conducted on this subject support these opinions/results. According to Köse [12] and İzci and Göktaş [13], in classes in which constructivist education approach is applied, teachers stated that time scheduled for activities is not enough, applications/activities that are found in guide books are not made enough [14], tools and materials are not used in classrooms, there are not different activities [15-16] and teachers use traditional education and evaluation criteria [17-18].

Regarding similar aspects of STEM education and constructivist education approach, teachers stated that STEM and constructivist education approach are student center. In both two approaches, children's developmental characteristics, individual differences, intelligences and learning preferences are taken into account. In other words, both two approaches handle children with a comprehensive concept of education (cognitive, affective and psychomotor domains), aim for children's learning by doing and experiencing, emphasize on scientific process skills, and expect that theoretical knowledge are converted into practice [19-5]. Regarding such an expectation, both two approaches assign teacher the task of "guidance." Teacher guides student's learning. These approaches are regarded as a product of information society's concept of education. Student is expected to use technology in this society's - in which technology is used swiftly - concept of education. Because in information society information change continually. Changing information is accessed via technology. In addition to that, STEM and constructivist education approach develop high level thinking skills in an individual [20-11-21]. Thus, it can be stated that common points of two approaches are individuals who can solve problems, see things from different perspectives, and analyze and synthesize.

As well as their similar aspects, there are also different aspects of STEM education and constructivist education approach. In STEM education certain disciplines are mentioned (Science, Technology, Engineering and Mathematics). In addition, it considers fields that can form a basis for other disciplines such as environment, economy, and medicine [22]. It aims to convert knowledge obtained throughout the process into practice [23]. However, in constructivist education approach, a specific discipline is not mentioned and knowledge obtained in the end of each discipline are related with each other. STEM education mentions "global literacy" skill [1]; on the other hand, in teaching programs in which constructivist education approach is used, concepts such as science literacy [24], "mathematical literacy skills" and technology literate [25] are used and different literacy skills for each course are mentioned. Difference of STEM education from constructivist education approach is not limited to those mentioned. STEM education prepares individuals to global economy together with developing technological age [5] and emphasizes on this point during trainings. However, in constructivist education approach, there is not such an explanation or emphasis. Also, in STEM education many approaches and models (Such as quantum learning, 
multiple intelligence theory, learning styles) are not mentioned. But in teaching programs in which constructivist education approach are applied, it is stated that children's intelligences and learning styles are different [26], and they construct the knowledge in a part-whole relationship.

\section{Recommendations}

- $\quad$ STEM education and constructivist education approach were compared in this research. For further studies, comparison of STEM education with different approaches/models and theories can be made.

- Contributions of teaching programs prepared according to STEM education on individuals' high level thinking skills can be investigated.

- Qualitative and quantitative studies can be conducted on student profiles in schools in which STEM education is applied.

\section{REFERENCES}

[1] Gülgün, C., Yılmaz, A. ve Çağlar, A. (2017). Teacher Opinions about the Qualities Required in STEM Activities Applied in the Science Course. Journal of Current Researches on Social Sciences(JoCReSS), 7 (1), 458-478, www.stracademy.org/jocress ISSN: 2547-9644

[2] Şahin, A., Ayar, M. C., and Adıgüzel, T. (2014). Fen, teknoloji, mühendislik ve matematik içerikli okul sonrası etkinlikler ve öğrenciler üzerindeki etkileri. Kuram ve Uygulamada Eğitim Bilimleri. 14(1), 1-26.

[3] Yıldırım, A ve Şimşek, H. (2006). Sosyal bilimlerde nitel araştırma yöntemleri. (5. Baskı). Ankara: Seçkin Yayınlar

[4] Morrison, J. (2006). TIES STEM education monograph series attributes of STEM education. https://www.partnersforpubliced.org

[5] Gökbayrak, S. \& Karıșan, D. (2017). STEM Etkinliklerinin Fen Bilgisi Öğretmen Adaylarının Bilimsel Süreç Becerilerine Etkisi. Batı Anadolu Eğitim Bilimleri Dergisi, 8(2), 2017.

[6] Wilson, Brent $G$ Reflections on Constructivism and lnstructional Design, Denver, Englewood Cliiffs NJ. Educational Technology Publications, 1997

[7] Abbott, L.F. \& T. Ryan 'Consstructing Knowledge, Reconstructing Schooling” Educational Leadership, November, 1999: 66-69.

[8] Hoşgörür, V. (2002). Sınıf yönetiminde yapısalcı yaklaşım Eğitim Araştırmaları Dergisi, 9, 73-78.

[9] Yanpar-Şahin,T. (2001). Oluşturmacı yaklaşımın Sosyal Bilgiler dersinde bilişsel ve duyuşsal öğrenmeye etkisi. Kuram ve Uygulamada Eğitim Bilimleri, 1, 463-482
[10] Perkins David N "The Many Faces of Constructivism." Educational Leadership, Novenber199:6-11.

[11] Brooks, J. And Brooks, M. (1999). In Search of Understanding: the Case for Constructivist Classrooms, Association for Supervision and Curriculum Development.

[12] Köse, E. (2011). 2005 ilköğretim matematik programının eğitsel eleştiri modeline göre değerlendirilmesi. Journal of Educational Science, 2(2), 1-11.

[13] İzci, E. and Göktaş, Ö. (2014). Matematik öğretmenlerinin 5. sınıf matematik dersi öğretim programına ilișkin görüşleri. Dumlupınar Üniversitesi Sosyal Bilimler Dergisi, 41, 317-328.

[14] Yazıcı, E. (2009). İlköğretim matematik dersi 6. sınıf öğretim programının değerlendirilmesi üzerine bir çalışma. Unpublished Doctoral Dissertation, Selçuk Üniversitesi, Konya.

[15] Aydoğdu, Ö. (2007). İlköğretim 6. sınıf matematik dersi geometri öğrenme alanının değerlendirilmesine ilişkin öğretmen görüşleri. Unpublished Master's Thesis, Gazi Üniversitesi, Ankara.

[16] Şahan, H. H. (2007). İlköğretim 3. sınıf matematik dersi öğretim programının değerlendirilmesi. Unpublished Doctoral Dissertation, Hacettepe Üniversitesi, Ankara.

[17] Kalender, A. (2006). Sınıf öğretmenlerinin yapılandırmac yaklaşım temelli yeni matematik programının uygulanması sürecinde karşılaştığı sorunlar ve bu sorunların çözümüne yönelik görüşleri. Unpublished Master's Thesis, Dokuz Eylül Üniversitesi, İzmir.

[18] Arseven, A., Arseven, İ. and Kontaş, H. (2014). Matematik programının değerlendirme ögesine ilişkin sınıf ögretmenlerinin görüşleri. Adıyaman Üniversitesi Sosyal Bilimler Enstitüsü Dergisi, 18, 657-677.

[19] Yıldırım, B., and Altun, Y. (2015). STEM Eğitim ve Mühendislik Uygulamalarının Fen Bilgisi Laboratuar Dersindeki Etkilerinin İncelenmesi. El-Cezerî Fen ve Mühendislik Dergisi, 2(2), 28-40.

[20] Çiftçi, Ö, (1998). Lise 1. Sınıf Öğrencilerinin Kullandıkları Öğrenme Stratejilerinin Matematik Dersindeki Akademik Başarıları Üzerindeki Etkisi (Unpublished Master's Thesis), Hacettepe Üniversitesi Sosyal Bilimler Enstitüsü,, Ankara.

[21] Kemertaş, İ., (2001). Uygulamalı Genel Öğretim Yöntemleri, İstanbul: Birsen Yayınevi.

[22] Gülhan, F. and Şahin, F. (2016). Fen-teknoloji-mühendislik-matematik entegrasyonunun (STEM) 5. sınıf öğrencilerinin bu alanlarla ilgili alg1 ve tutumlarına etkisi. International Journal of Human Sciences, $13(1), 602-620$

[23] Çorlu, M. (2013). Uzman alan öğretmeni eğitimi modeli ve görüşler. http://fetemm.tstem.com/gorusler.

[24] MEB (2017). Fen Bilimleri Dersi Öğretim Programı (İlkokul ve Ortaokul 3, 4, 5, 6, 7 ve 8. Sinıflar) (Retrieved 13.10.2017, from https://ttkb.meb.gov.tr/

[25] MEB (2017). Matematik Dersi Öğretim Programı (İlkokul ve Ortaokul 1, 2, 3, 4, 5, 6, 7 ve 8. Siniflar) (Retrieved 13.10.2017, fromhttps://ttkb.meb.gov.tr/) 

Is the Constructivist Education Approach Preparatory to the STEM Education?

[26] MEB (2017). Teknoloji ve Tasarım Dersi Öğretim Programı (Ortaokul 7 ve 8. Sinıflar) (Retrieved 13.10.2017,

\footnotetext{
This article is an improved version of a paper presented orally in 1st International Teacher Education and Accreditation Congress, 19-21 May 2017, Istanbul/Turkey.
}

from https://ttkb.meb.gov.tr/). 